\title{
Land evaluation for crop production in Upper Kabete Campus field, University of Nairobi, Kenya
}

\author{
Samuel M. Mwendwa * (D, Joseph P. Mbuvi and Geoffrey Kironchi
}

\begin{abstract}
Background: The study area exhibits a first class catena; variation in soils is a result of differences in drainage and lateral movement of materials. The site was delineated into Soil Mapping Units (SMUs) through augering, into soils differing in macro relief. Slope categories included 0 to $5 \%, 5$ to $8 \%, 8$ to $16 \%, 16$ to $30 \%$ and $>30 \%$. Profile pits were opened in the five mapping units using stratified random sampling technique. Identified SMUs include UmIr/F, UmIr/E, UxIr/D, UxIr/C and UxIr/AB in order of decreasing slope gradient. Land suitability classification was based on the top horizons and the FAO 1976 criterion for land evaluation was used. The study aimed at identifying the most suitable areas for envisaging production of common crops grown in the area and limitations to production increase. A table of relevant land qualities and their diagnostic factors was constructed, rated and matched with suitability classdefining criteria to determine current suitability. Potential suitability was determined by considering the possibility of resolving the current limitations.

Results: Mapping unit Umlr/F and Umlr/E qualified as class S2 for the selected crops majorly due to limitations of workability and susceptibility to erosion based on their slope gradient. Nutrient availability and possibility of use of implements also rated as S2. Unit UxIr/D qualified in S2 category due to the same limitations. Mapping unit UxIr/C and UxIr/AB qualified in the S2 category due to limitations of nutrient availability. After improvements, all the mapping units qualified in class S1.

Conclusions: These observations indicate that workability and erosion susceptibility due to steep topography coupled with lack of enough nutrients are the greatest production limitations in the study area. Increasing slope gradient also led to decreasing possibility of use of farm implements. Terracing can reduce the deleterious influence of slope on soil quality, shifting suitability to a higher class, should the steep area be used for cultivation. There is a need for sufficient inputs and cover cropping to maintain high soil quality. Land evaluation should be part of good agricultural practices in any production system.
\end{abstract}

Keywords: Catena, Soil Mapping Units, Stratified random sampling, Land qualities, Diagnostic factors

\section{Introduction}

There is evidence of suboptimal land use in Kabete; area under rough grazing can be used for pasture and irrigated with water that flows by gravity from hostels and the kitchen. The soils have not been mapped in details and there is limited effort in the subject of soil survey

\footnotetext{
*Correspondence: samuelmwendwa2@gmail.com

Department of Land Resource Management and Agricultural Technology,

College of Agriculture and Veterinary Sciences, University of Nairobi,

Kangemi, P.O. Box 29053-00625, Nairobi, Kenya
}

and land evaluation, which could lead to inappropriate land use practices. There is a need for land evaluation so as to envisage utilization types where they best fit. Land evaluation determines the capacity of a land to sustain a specified use. Relevant land qualities are compared with the requirements of the use to determine the suitability class. Different classes have different production potentials. Only the relevant land qualities and their respective diagnostic factors are taken into account. 
Land suitability classification examines the degree of land suitability for various utilization types [1] and how the land can adapt to specific land use practices. It is a comprehensive elucidation of the potential productivity of a given field [2]. Soil maps provide a key basis for land suitability analysis [3] and despite detailed maps with good resolution being scanty, attempts to overcome this difficult scenario have been expensive [4]. Since land characteristics are spatially variable over very fine scales, there is need for detailed soil surveys [5].

Unused good agricultural land is very scarce; marginally suitable areas are being converted into agricultural lands due to increasing demand for food with the increasing population [6]. Yields can be improved by increasing production per unit area or by increasing cultivated area, the latter being in real sense impracticable. Different plants require different soil conditions for optimum performance, and therefore availability of water and nutrients in the soil largely influences crop production. Different plant species have different rooting depths requiring variable soil conditions. Characteristics including soil depth, texture, salinity and drainage are related to soil quality. Digital soil maps help in evaluating land for suitability of various crops as well as identifying sites for location of structures for instance fish ponds, therefore necessitating land use planning.

Land evaluation estimates land suitability for different alternative uses [7]. It is the interface between land resource surveys and management of the land and determines the capacity of the land to sustain a specific use whilst identifying limitations to production increase [8]. Conducting a land suitability analysis involves the integrating of a number of factors including soil characteristics, suitability of crops to different soil properties, relief, parent material and geomorphology, social and technical attributes. Land qualities that affect plant growth, yield and biomass production and are relevant within the socio-economic and physical situation of the area are considered in expressing crop requirements [9]. Land suitability analysis predicts how the land would perform if used according to each of the proposed systems $[10,11]$. This study aimed at assessing the suitability of different tracks of the study site for crop production and to determine possible improvements in the current management practices by dealing with current limitations so as to increase crop production.

\section{Materials and methods \\ Study site}

This research was done in Upper Kabete Campus field, University of Nairobi. The site lies between 247653,
9861440 and 1876 (UTM) longitude, latitude and altitude, respectively. The site is part of the Loresho Ridge which is an upland characterized by slopes ranging from 0 to 32\% (Fig. 2). It is categorized under Agro ecological Zone III, having bimodal rainfall distribution with long rains starting in March or April and ending in June; short rains start in October and end in January. The climate is typically sub-humid [12]. The geology comprises the Kabete grey-green porphyritic trachyte of middle division of tertiary age [13] overlying the Nairobi trachyte and Kirichwa valley tuffs. These rocks are overlain elsewhere by the Limuru-Karura trachytes and are equivalent in age with the Ruiru Dam trachyte.

Upper Kabete campus has a built area with all the necessary student facilities that produce waste water which is currently not utilized. There is a cultivated area which is used for commercial farming with coffee and horticultural crops as the main enterprise. The other area is used for research trials for both faculty and postgraduate students. The bigger portion of the land is left for grazing livestock that are used for teaching veterinary science and for biogas production which is used in the student kitchens. There are future plans to build purification tanks for the waste water in order to increase fodder production through irrigation. There is a stream that runs between the cultivated area which has been dammed at the lowest point of the study site and which provides water to the coffee factory and for supplemental irrigation for both research and commercial horticultural production. This study will act as a guiding document to improve on proper land utilization.

\section{Soil survey procedure}

A reconnaissance field visit was done in preparation for field work. One hundred and sixty-four (164) auger holes were made to a depth of $100 \mathrm{~cm}$ across the study area. Garmin Etrex Global Positioning System (GPS) and a Suunto clinometer were used to take coordinates and slope percentages, respectively. Auger points were used to delineate the study area into SMUs based on slope classes and these delineations were the strata within which profiles were opened following stratified random sampling technique. A slope map was produced using detailed interpolation procedures in Arcview GIS 3.3 software (Fig. 1).

The mapping units, 0 to $5 \%, 5$ to $8 \%, 8$ to $16 \%, 16$ to $30 \%$ and $>30 \%$, were connoted as flat to gently undulating $(A B)$, undulating $(C)$, rolling $(D)$, hilly $(E)$ and mountainous (F), respectively. Profile pits were opened across the SMUs with profile 7 representing $>30 \%$ slope, profile 5 and 6 representing 16 to $30 \%$, profile $1,2,4$ and 14 representing 8 to $16 \%$, profile $3,8,9,11$ and 13 representing 5 to $8 \%$ and profile $10,12,15$ and 16 representing 0 
to $5 \%$ slope. The profiles were described and samples for chemical and physical analyses collected.

\section{Soil analysis}

Sample preparations were done at the departmental laboratory. Soil reaction was measured with a glass electrode $\mathrm{pH}$ meter [14]. Organic $\mathrm{C}$ and total $\mathrm{N}$ were determined using the Walkley-Black method as lucidly exposed by [15] and steam distillation [16], respectively. Base saturation and CEC were determined according to [17]; K and $\mathrm{Na}$ were measured using a flame photometer; $\mathrm{Ca}$ and $\mathrm{Mg}$ were analysed using the Atomic Absorption Spectrophotometer (AAS) at element specific spectral signatures. Soil texture was determined using the hydrometer (Bouyoucos) method as elucidated by [18]. Saturated hydraulic conductivity (Ksat) was determined according to [19] and the same sample used for determining bulk density [20]. These methods are in [14].

\section{Generation of Soil Mapping Units map}

Kriging interpolator was used because it scientifically assumes that the distance between sample spots shows spatial correlation; that closer points are more related compared to widely spaced points. It gives the best linear unbiased prediction of intermediate values and is able to estimate the variance at each point; hence, the spatial accuracy of the interpolation can be judged. It is the most appropriate tool for measuring spatial dependence by examining the semivariogram. Sample points were loaded in ArcMap 10.1, spatial analyst expanded in the Arc toolbox, interpolation selected and kriging tool chosen. Sample points were selected as input and slope percentage as the $Z$ value field. The raster surface to be generated was named in the Output surface raster field. Ordinary kriging was chosen as interpolation method and circular as semivariogram model. The map was further digitized and given a comprehensive legend (Fig. 2).

\section{Land suitability classification}

The use being evaluated in this study is land suitability for growing of various crops including maize, beans and coffee. Research and trial portions are usually planted with different crops in different seasons. The typically sub-humid climate was assumed to be favourable for crop production and that inputs would be available such as fertilizers, water, labour and pesticides. Only the relevant land qualities were taken into account. Principles followed include the fact that the suitability of a land is assessed and classified with respect to

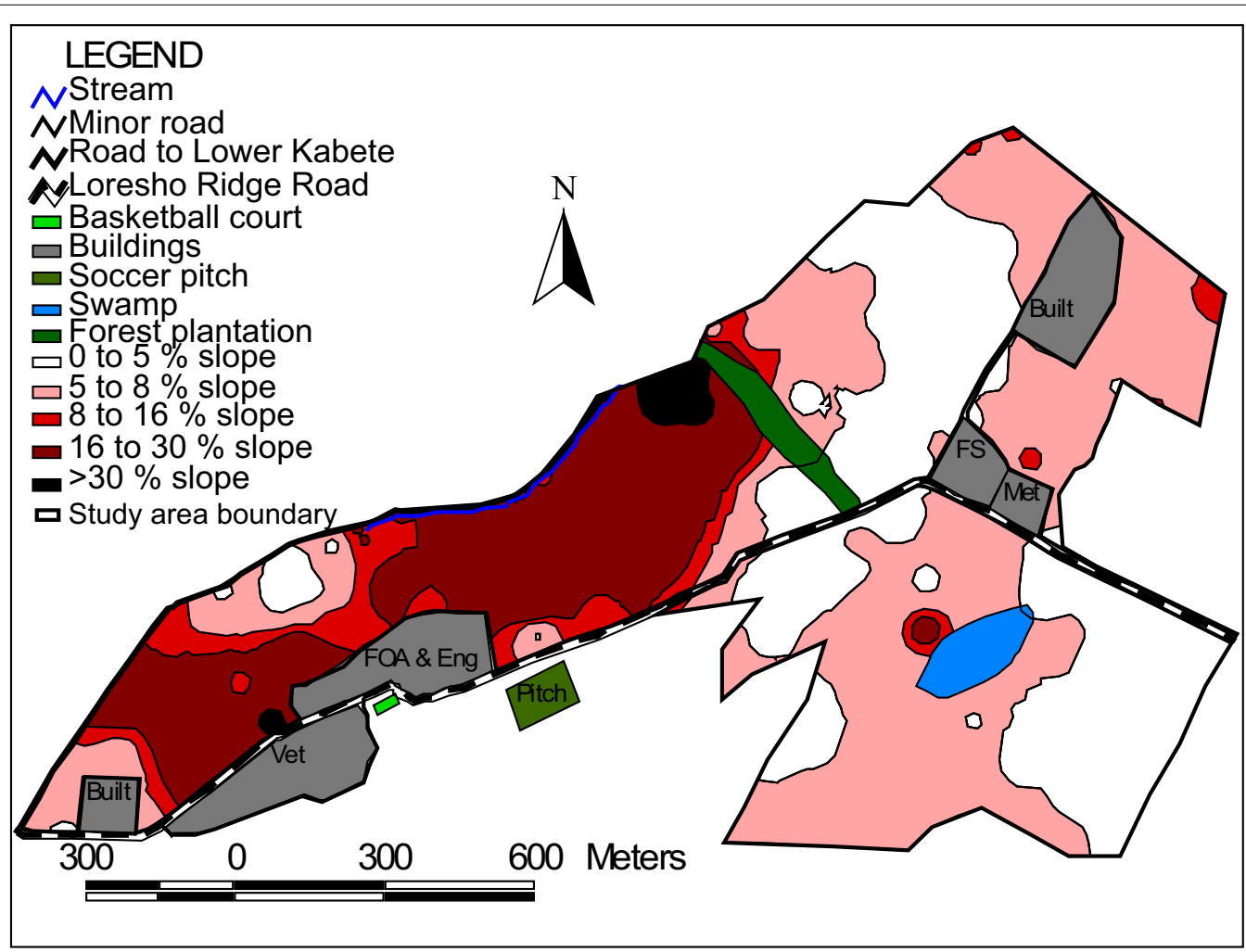

Fig. 1 Study area map showing slope categories 
specified kinds of use and land suitability refers to use on a sustainable basis.

Relevant tables were constructed including a table of relevant physicochemical data (Table 1) and land qualities alongside their diagnostic factors (Table 2). The land utilization types were described in terms of soil and climatic requirements. Tables of factor rating giving the land qualities suitability ratings were also constructed (Tables 3, 4, 5, 6, 7) and the land qualities rated in all the mapping units (Table 8). A conversion table (Table 9) for the matching process to compare the rated factor rating and crop requirements was constructed to give the current and potential suitability of the mapping units (Table 10). The class of the land was the lowest suitability (S); for example, having S1 and S2, the class was assigned S2. Potential suitability was determined based on ability to address the current limitations.

\section{Results}

\section{Soil classification}

In the study area, only Nitisols were identified as influenced by climate and geology of the study site. Nitisols have an argic B horizon with clay distribution that does not show relative decrease from its maximum of more than $20 \%$ within $150 \mathrm{~cm}$ of the surface, with gradual boundary between $\mathrm{A}$ and $\mathrm{B}$ horizons and having nitic properties. Only Humic Nitisols were found because of the occurrence of a mollic A horizon, very fine, mixed isothermic oxic Humiustalf: Soil Taxonomy. The soils were classified as Eutric Humic Nitisols at the third level due to its strong expression of the base saturation.

Soil Classification was based on Technical Paper No. 20 by FAO-UNESCO Soil Map of the World, published by ISRIC, Wageningen, 1997 and The World reference base for soil resources, 2006 [21].

Figure 2 presents the various Soil Mapping Units which were identified during the field study and which were used for data collection and land evaluation.

Table 1 shows textural and chemical properties of the profiles in the various mapping units.

\section{Description of the land utilization types (LUTs)}

Land suitability evaluation was done for coffee, maize, beans, pigeon peas and horticultural crops including spinach, potatoes and onions. These LUTs require high capital input in terms of fertilizers, labour, pesticides and certified seeds. They also require good and high standard agronomic practices so as to accrue benefits from high-quality produce. These good agronomic practices include timely land preparation, weeding, crop rotation and good marketing. Coffee, onions and spinach require good nursery management and proper transplanting. Potatoes require ridging for good tuber development. Proper agronomic management will prevent the deleterious effects of pests and diseases on crops. Among the practices include the use of certified seeds, field hygiene, burning weeds and diseased materials and timely application of inputs.

\section{Soil and climate requirements for selected crops}

Coffee performs best on well-drained, fertile, deep sandy loams having a $\mathrm{pH}$ range of 4.4 to 5.4 preferably in cool humid climates making it ideal to the predominantly acidic soils of the study area. Maize is adapted to a wide range of soils and climate but performs best on well-drained loam soil with $\mathrm{pH}$ ranging from 6.0 to 7.2 and medium conditions of temperature and rainfall. Pigeon peas require well-drained, sandy loam to loam non-saline soils and are adapted to medium to high temperatures. Potatoes require well-drained, fairly deep sandy loam to medium loam soils rich in organic matter. They prefer medium to high temperatures. Onions perform best on sandy loams and loams with high organic matter content, good drainage, good water holding capacity and a $\mathrm{pH}$ of 6.0 to 6.7. Beans perform best on well-drained and fertile soils that have adequate water holding capacity, adequate organic matter content and $\mathrm{pH}$ values of 5.8 to 7.0. Spinach performs best on well-drained, fertile, sandy loams and loams with high organic matter and a $\mathrm{pH}$ range of 5.8 to 6.8 .

\section{Land qualities and their ratings}

A land quality is a complex attribute of land which acts in distinctive manner in its influence on the suitability of land for a specific kind of use. The following land qualities were recognized:

Other qualities including the rooting condition, oxygen availability and excess salts whose diagnostic factors include effective soil depth, drainage class and salinity class, respectively, are important in crop production but were deliberately overlooked. This is because the soils of the study area are deep to very deep $(>100 \mathrm{~cm})$, well drained and non-saline; therefore, these land qualities could have been of limited value in this evaluation. Rockiness was not rated as a factor of workability because the rocky areas were mapped separately (Fig. 2).

\section{Factor rating}

Selected land qualities were compared, using their diagnostic factors, with land characteristics to establish the suitability of each defined soil mapping unit with regard to crop production. Qualitative and quantitative properties of the mapping units (what the soil can supply) were compared with crop requirements and ranked among the following land suitability orders and classes. 


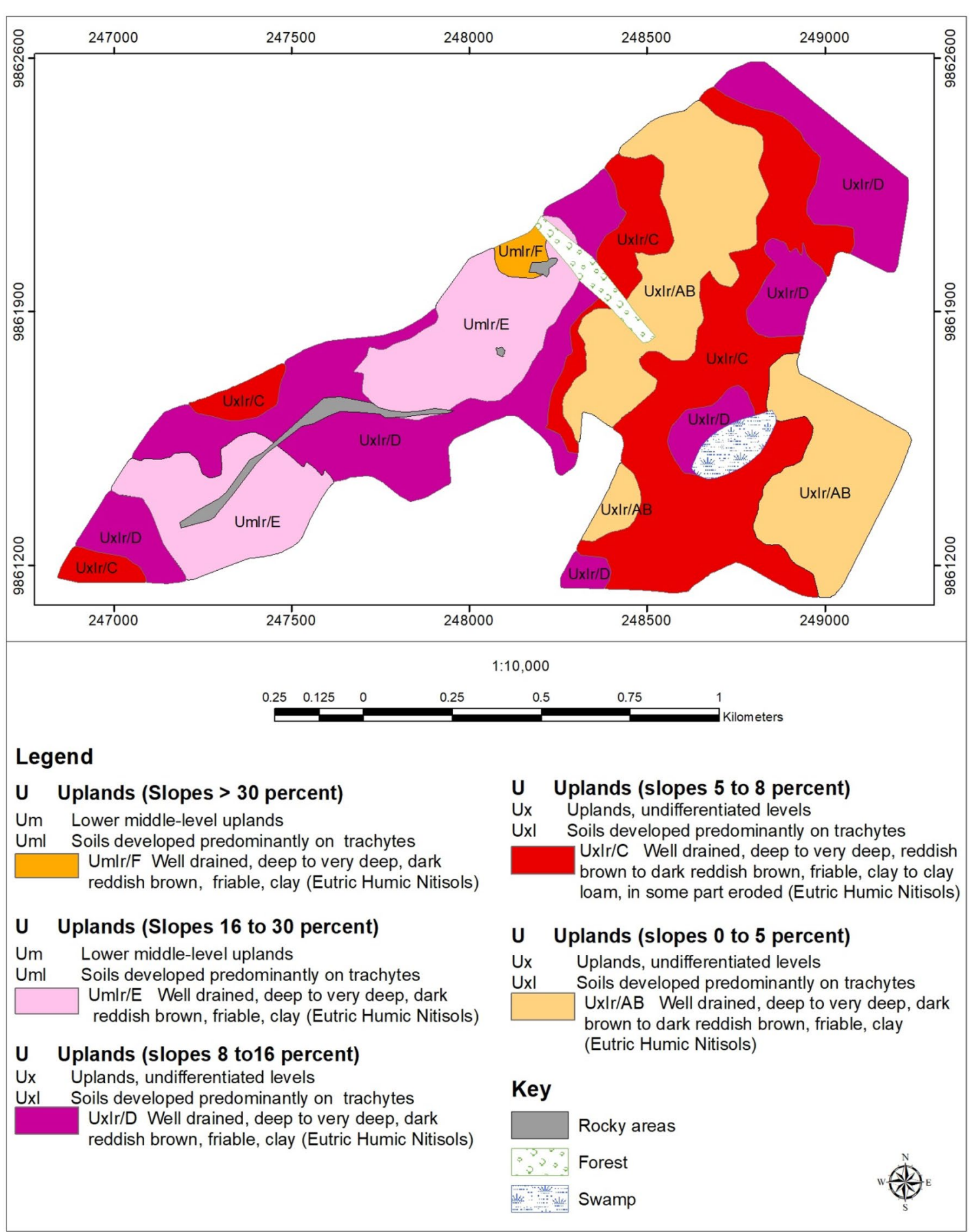

Fig. 2 Soil map of upper Kabete campus area (source: Author) 
Table 1 Relevant physical and chemical data for the profiles

\begin{tabular}{|c|c|c|c|c|c|c|c|c|c|c|c|c|c|}
\hline \multirow[t]{2}{*}{ Map unit } & \multicolumn{13}{|l|}{ Texture } \\
\hline & Profile & Horizon & Depth & $S$ & SI & $C$ & TC & $\mathrm{pH}$ & $\mathrm{EC}$ & $\% O C$ & $\% N$ & CEC & BS\% \\
\hline Umlr/F & $148 / 4-7$ & Ap & $0-14$ & 22 & 14 & 64 & C & 6.1 & 0.1 & 2.95 & 0.39 & 22.2 & 92 \\
\hline \multirow[t]{3}{*}{ Umlr/E } & $148 / 4-5$ & A & $0-16$ & 26 & 8 & 66 & C & 5.6 & 0.2 & 3.18 & 0.35 & 15.6 & 90 \\
\hline & 148/4-6 & A & $0-33$ & 30 & 22 & 48 & C & 6.2 & 0.1 & 4.03 & 0.49 & 27.6 & 94 \\
\hline & & $A B$ & $33-53$ & 24 & 24 & 52 & $C$ & 6.2 & 0.1 & 2.33 & 0.28 & 23.8 & 93 \\
\hline \multirow[t]{6}{*}{ UxIr/D } & $148 / 4-2$ & A & $0-23$ & 31 & 30 & 39 & $\mathrm{CL}$ & 6.2 & 0.1 & 3.45 & 0.39 & 23.2 & 91 \\
\hline & $148 / 4-14$ & Ap & $0-15$ & 45 & 27 & 28 & $\mathrm{CL}$ & 5.7 & 0.1 & 2.55 & 0.2 & 20 & 70 \\
\hline & $148 / 4-4$ & A & $0-27$ & 32 & 22 & 46 & C & 6.4 & 0.1 & 3.8 & 0.42 & 27 & 93 \\
\hline & & $A B$ & $27-38$ & 30 & 20 & 50 & C & 5.9 & 0.1 & 3.37 & 0.24 & 22 & 87 \\
\hline & 148/4-1 & A & $0-16$ & 40 & 8 & 52 & C & 5.7 & 0.2 & 3.68 & 0.36 & 23 & 73 \\
\hline & & $A B$ & $16-35$ & 32 & 14 & 54 & C & 5.9 & 0.1 & 2.25 & 0.35 & 21.8 & 60 \\
\hline \multirow[t]{7}{*}{ UxIr/C } & $148 / 4-3$ & A & $0-21$ & 32 & 22 & 46 & $C$ & 5.9 & 0.2 & 3.95 & 0.56 & 25.8 & 68 \\
\hline & & $A B$ & $21-45$ & 30 & 20 & 50 & $C$ & 6.6 & 0.1 & 2.17 & 0.24 & 21.8 & 91 \\
\hline & $148 / 4-8$ & Ap & $0-17$ & 47 & 23 & 30 & $\mathrm{SCL}$ & 5.9 & 0.2 & 3.14 & 0.34 & 21.2 & 92 \\
\hline & 148/4-9 & Ap & $0-21$ & 51 & 27 & 24 & $\mathrm{SCL}$ & 5.4 & 0.3 & 3.3 & 0.32 & 24.4 & 52 \\
\hline & 148/4-11 & Ap & $0-25$ & 30 & 30 & 40 & $\mathrm{CL}$ & 5.7 & 0.1 & 1.51 & 0.56 & 23 & 94 \\
\hline & 148/4-13 & Ap & $0-15$ & 30 & 16 & 54 & C & 6.2 & $\mathrm{TR}$ & 1.99 & 0.28 & 19.2 & 92 \\
\hline & & $A B$ & $15-38$ & 26 & 18 & 56 & C & 5.9 & 0.1 & 1.8 & 0.13 & 18.6 & 83 \\
\hline \multirow[t]{8}{*}{ UxIr/AB } & 148/4-10 & Ap & $0-16$ & 36 & 32 & 32 & $\mathrm{CL}$ & 6.3 & 0.2 & 2.05 & 0.27 & 16 & 91 \\
\hline & & $A B$ & $16-38$ & 36 & 26 & 38 & $\mathrm{CL}$ & 6.6 & 0.1 & 2.13 & 0.22 & 26 & 95 \\
\hline & 148/4-16 & $A p$ & $0-25$ & 44 & 24 & 32 & $\mathrm{CL}$ & 5.5 & $\mathrm{TR}$ & 2.4 & 0.22 & 20.4 & 93 \\
\hline & & $A B$ & $25-51$ & 46 & 12 & 42 & C & 5.6 & 0.1 & 2.1 & 0.24 & 18.2 & 92 \\
\hline & 148/4-15 & $A p$ & $0-18$ & 28 & 34 & 38 & $L$ & 5.6 & 0.1 & 2.73 & 0.43 & 20.2 & 70 \\
\hline & & $A B$ & $18-45$ & 28 & 30 & 42 & C & 6.4 & $\mathrm{TR}$ & 2.51 & 0.29 & 23.4 & 94 \\
\hline & $148 / 4-12$ & Ap & $0-18$ & 35 & 40 & 25 & $\mathrm{~L}$ & 5.8 & 0.1 & 1.55 & 0.35 & 18 & 78 \\
\hline & & $A B$ & $18-32$ & 41 & 32 & 27 & $L$ & 5.9 & 0.1 & 1.24 & 0.43 & 21.4 & 72 \\
\hline
\end{tabular}

$S$ sand, $S /$ silt, $C$ clay, $T C$ textural class, $p H$ potential of hydrogen, $E C$ electrical conductivity, $O C$ organic carbon, $N$ nitrogen, $C E C$ cation exchange capacity, $B S$ base saturation

Table 2 Land qualities and respective diagnostic factors

\begin{tabular}{ll}
\hline Land quality & Diagnostic factor(s) \\
\hline Nutrient availability & Soil reaction $(\mathrm{pH})$ \\
& Cation exchange capacity (CEC) \\
Soil workability & Slope class \\
& Texture \\
Susceptibility to erosion & Slope angle \\
$\begin{array}{l}\text { Possibilities for the use of agricultural } \\
\text { implements }\end{array}$ & Slope steepness \\
\hline
\end{tabular}

Table 3 Suitability classes

\begin{tabular}{lll}
\hline Order & Class & Descriptive \\
\hline Suitable (S) & S1 & Highly suitable \\
& S2 & Moderately suitable \\
Not suitable (N) & S3 & Marginally suitable \\
& N1 & Currently not suitable \\
& N2 & Permanently not suitable
\end{tabular}

\section{Ratings of selected land qualities}

\section{Nutrient availability}

The productivity of the soil is largely dependent on its capacity to retain nutrients. This quality is largely determined by the levels of soil reaction and Cation Exchange Capacity.

\section{Workability}

The diagnostic characteristics for workability include slope class, texture and surface stoniness that determine the effectiveness of use of farm implements at different moisture conditions. Increasing slope, clay percentage and surface stoniness lead to poor soil workability.

\section{Susceptibility to erosion}

It was determined by slope angle and slope length, the slope angle being the key determinant of erosion susceptibility. Table 6 shows the ratings for slope steepness. 
Table 4 Rating for nutrient availability

\begin{tabular}{lll}
\hline Rating & Soil reaction $(\mathrm{pH})$ & CEC \\
\hline 1 & $5.6-7.3$ & $\geq 24$ \\
2 & $5.1-5.5$ & $16-24$ \\
3 & $4.5-5.0$ & $10-15$ \\
4 & $<4.5$ & $<10$ \\
\hline
\end{tabular}

Table 5 Rating for workability

\begin{tabular}{lll}
\hline Rating & Slope class (\%) & Texture \\
\hline 1 & $0-5$ & L-SCL \\
2 & $06-$ DeC & CL-SC \\
3 & $13-16$ & $C$ \\
4 & $>16$ & $C$ \\
\hline
\end{tabular}

Table 6 Rating for erosion hazard

\begin{tabular}{lll}
\hline Ratings & Slope $\%$ & Description \\
\hline 1 & $0-2$ & Very low \\
2 & $2-5$ & Low \\
3 & $5-8$ & Moderate \\
4 & $8-16$ & High \\
5 & $16->30$ & Very high \\
\hline
\end{tabular}

Table 7 Possibilities for the use of agricultural implements

\begin{tabular}{ll}
\hline Rating & $\begin{array}{l}\text { Slope } \\
\text { steepness } \\
(\%)\end{array}$ \\
\hline 1 & $0-2$ \\
2 & $2-5$ \\
3 & $5-8$ \\
4 & $8-16$ \\
5 & $16->30$ \\
\hline
\end{tabular}

\section{Possibilities for the use of agricultural implements}

This is depended on slope steepness, slope length, stoniness, rockiness or shallowness of the soil and workability of the top soil, with slope steepness being more relevant to this study.

\section{Suitability class-defining criteria}

Selected crops have different land use requirements that were rated according to the selected land qualities. Table 9 shows the conversion table per crop for the given land qualities.

\section{Matching \\ Results of suitability evaluation for selected crops}

Since coffee is mostly planted on gentle slopes, it was only evaluated in mapping units UxIr/D, UxIr/C and UxIr/AB. Possibility of use of farm implements was not deemed to be a major limitation in evaluating the suitability of the crops except for coffee because hand cultivation is practised in the steep areas. Table 10 shows the current and potential suitability for growing of the selected crops. This is a matching of land quality of each soil mapping unit with the suitability class-defining criteria (conversion table for the crops) to obtain the final suitability. The law of the minimum was applied whereby the lowest single rating of one of the land qualities determined the suitability class of the mapping unit for the specific crop.

\section{Discussion}

Final Suitability Classification

Soil workability, susceptibility to erosion hazard and little possibility for the use of implements were the greatest production limitations in UmIr/F and UmIr/E due to slope classes greater than $16 \%$. The clay texture of the study area is not a limitation to crop production because it is composed of kaolinite, a 1:1 clay mineral having favourably good workability at variable moisture conditions. However, use of heavy machinery when the soils are wet should be avoided to prevent compaction. It is

Table 8 Rating of land qualities in all the mapping units

\begin{tabular}{|c|c|c|c|c|}
\hline \multirow[t]{2}{*}{ Land mapping unit } & \multicolumn{4}{|l|}{ Land quality } \\
\hline & Nutrient availability (n) & Workability (k) & Erosion susceptibility (e) & $\begin{array}{l}\text { Use of agricultural } \\
\text { implements (m) }\end{array}$ \\
\hline Umlr/F & $1-2$ & 4 & 4 & $4(2)$ \\
\hline Umlr/E & $1-2$ & 4 & 4 & $3(2)$ \\
\hline UxIr/D & $1-2$ & $2-3$ & $2-3$ & $2(1)$ \\
\hline UxIr/C & $1-2$ & $1-2$ & $1-2$ & $1(1)$ \\
\hline UxIr/AB & $1-2$ & 1 & 1 & $1(1)$ \\
\hline
\end{tabular}

() applies to hand and ox cultivation 
Table 9 Conversion table for selected crops

\begin{tabular}{|c|c|c|c|c|c|}
\hline Crop & Suitability class & Nutrient availability (n) & Workability (k) & Erosion susceptibility (e) & Use of implements (m) \\
\hline \multirow[t]{4}{*}{ Coffee } & S1 & 1,2 & 1,2 & 1,2 & 1,2 \\
\hline & S2 & 3 & 3 & 3 & 3,4 \\
\hline & S3 & 3 & 4 & 4 & 5 \\
\hline & $\mathrm{N}$ & 4 & 4 & 5 & 5 \\
\hline \multirow[t]{4}{*}{ Maize } & S1 & 1 & 1,2 & 1,2 & 1,2 \\
\hline & S2 & 2 & 3,4 & 3,4 & 3,4 \\
\hline & S3 & 3 & 3,4 & 4 & 5 \\
\hline & $\mathrm{N}$ & 4 & 3,4 & 5 & 5 \\
\hline \multirow[t]{4}{*}{ Beans } & S1 & 1 & 1,2 & 1,2 & 1,2 \\
\hline & S2 & 2 & 3,4 & 3,4 & 3,4 \\
\hline & S3 & 3 & 3,4 & 4 & 5 \\
\hline & $\mathrm{N}$ & 4 & 3,4 & 5 & 5 \\
\hline \multirow[t]{4}{*}{ Pigeon peas } & S1 & 1 & 1,2 & 1,2 & 1,2 \\
\hline & S2 & 2 & 3,4 & 3,4 & 3,4 \\
\hline & S3 & 3 & 3,4 & 4 & 5 \\
\hline & $\mathrm{N}$ & 4 & 3,4 & 5 & 5 \\
\hline \multirow[t]{4}{*}{ Potatoes } & S1 & 1 & 1,2 & 1,2 & 1,2 \\
\hline & S2 & 2 & 3,4 & 3,4 & 3,4 \\
\hline & S3 & 3 & 3,4 & 4 & 5 \\
\hline & $\mathrm{N}$ & 4 & 3,4 & 5 & 5 \\
\hline \multirow[t]{4}{*}{ Onions } & S1 & 1 & 1,2 & 1,2 & 1,2 \\
\hline & S2 & 2 & 3,4 & 3,4 & 3,4 \\
\hline & S3 & 3 & 3,4 & 4 & 5 \\
\hline & $\mathrm{N}$ & 4 & 3,4 & 5 & 5 \\
\hline \multirow[t]{4}{*}{ Spinach } & S1 & 1 & 1,2 & 1,2 & 1,2 \\
\hline & S2 & 2 & 3,4 & 3,4 & 3,4 \\
\hline & S3 & 3 & 3,4 & 4 & 5 \\
\hline & N & 4 & 3,4 & 5 & 5 \\
\hline
\end{tabular}

Table 10 Current and potential suitability

\begin{tabular}{|c|c|c|c|c|c|c|c|c|c|c|}
\hline \multirow[t]{3}{*}{ Crops } & \multicolumn{10}{|c|}{ Mapping units } \\
\hline & \multicolumn{2}{|l|}{ Umlr/F } & \multicolumn{2}{|l|}{ Umlr/E } & \multicolumn{2}{|l|}{ UxIr/D } & \multicolumn{2}{|c|}{ UxIr/C } & \multicolumn{2}{|c|}{ UxIr/AB } \\
\hline & Curr & Pot & Curr & Pot & Curr & Pot & Curr & Pot & Curr & $\overline{\text { Pot }}$ \\
\hline Coffee & - & - & - & - & s2ke & s2ke & S1 & S1 & S1 & S1 \\
\hline Maize & s2nkem* & S1 & s2nkem* & $\mathrm{S} 1$ & s2nke & S1 & $S 2 n$ & S1 & $S 2 n$ & S1 \\
\hline Beans & s2nkem* & S1 & s2nkem* & $\mathrm{S} 1$ & S2nke & S1 & $S 2 n$ & S1 & $S 2 n$ & S1 \\
\hline Pigeon peas & s2nkem* & S1 & s2nkem* & $\mathrm{S} 1$ & s2nke & S1 & $S 2 n$ & S1 & $S 2 n$ & S1 \\
\hline Potatoes & s2nkem* & S1 & s2nkem* & $\mathrm{S} 1$ & s2nke & S1 & $S 2 n$ & S1 & $S 2 n$ & S1 \\
\hline Onions & s2nkem* & S1 & s2nkem* & $\mathrm{S} 1$ & s2nke & S1 & $S 2 n$ & S1 & $S 2 n$ & S1 \\
\hline Spinach & s2nkem* & S1 & s2nkem* & $\mathrm{S} 1$ & s2nke & S1 & $\mathrm{s} 2 \mathrm{n}$ & S1 & $\mathrm{S} 2 \mathrm{n}$ & S1 \\
\hline
\end{tabular}

Curr current suitability, Pot potential suitability

* Possibility for use of farm implements $(\mathrm{m})$ is as given but for hand and ox cultivation S1

impractical to alter the slope of the land unless an engineering adventure is anticipated; therefore, erosion control measures would be of great benefit to prevent runoff in these mapping units.
UxIr/D qualified in the S2 category majorly due to limitations of susceptibility to erosion and poor workability, having a slope percent lying between S1 and S2. Except for coffee that can thrive in low $\mathrm{pH}$, nutrient availability 
qualified for S2 for the rest of the crops. Terracing can reduce the deleterious influence of slope on soil quality, shifting suitability to a higher class. Mapping unit UxIr/C and UxIr/AB qualified in the S2 category due to limitations of nutrient availability except for coffee that rated as S1. These limitations are relatively easy to manage. These observations indicate that workability due to slope percent, erosion susceptibility, impracticability in use of farm implements in steep areas and lack of enough nutrients are the greatest production limitations in the study area.

\section{Potential suitability}

It is the suitability of the land at some future date after undertaking some improvements, major or minor. Mapping units having limitations that can be reduced or solved by good management practices can be highly suitable after the improvements. Nutrient availability can be improved by addition of well-decomposed organic manure to buffer the soil reaction and to improve the CEC. The use of acidifying fertilizers such as Diammonium Phosphate (DAP) is strongly discouraged since the soils are predominantly acidic. Use of basic fertilizers such as Calcium Ammonium Nitrate is recommended. Improving soil workability is challenging due to the static nature of some of the diagnostic factors. However, the soil texture can be managed over a period of time and would not be a limitation to crop production in the study area if the soils are well supplied with organic amendments. Organic materials can lighten the clay texture, improving the workability and drainage therefore elevating the suitability to a higher class. Preventing runoff through terracing, cover cropping and contour cultivation in sloping areas can help to maintain the soil fertility and prevent the impact of rain drops and wind erosion. All the mapping units shifted to S1 for the selected crops in future because of the generally good physical and chemical properties of the soils and favourable climatic condition of the study area. Encountered limitations can be managed or resolved with relative ease. Given the bimodal rainfall pattern in the study area, the implication is that the long rains are more reliable for growth of annual crops compared to short rains.

This study was driven by the need to have proper understanding of crop production potential in different mapping units. The mapping units were delineated based on slope percentage and used as strata for soil sampling. The key concept was to analyse the soils to know their fertility and physical properties, as well as to examine the landscape for slope gradient, and then examine their suitability for growth of common crops in the area. Land evaluation exercises have not been a commonplace good agricultural practice in Kenya leading to improper utilization of the land by failing to put enterprises where they best fit.

Few studies in the same line have been done in Kenya: Irrigation suitability assessment was done in 1977 on the soils of valley bottoms of Kabete Veterinary Laboratories, aiming to find whether the soil and water were suitable for irrigation of lucerne, napier and alfalfa. They were found to be suitable. Land suitability has been carried out in the Mount Kulal/Marsabit area of northern Kenya to determine land suitability for nomadic grazing. Used land qualities included accessibility, resistance to erosion, salinity and moisture availability of the soils. The mutual effect of their diagnostic characteristics determined the suitability of different areas for grazing various animals. The study aimed to improve pastoral lifestyle as well as prevent land degradation. The Chalbi desert was classified as unsuitable for grazing of all livestock species. The most striking observation was that pastoralists avoided highly suitable areas for religious, social and inter-tribal security reasons and sometimes used areas classified as unsuitable. This is a policy implication and a wake-up call to embrace land evaluation as key to achieving sustainable development goals (SDGs) pertaining alleviation of hunger, poverty and for environmental protection.

A major limitation to undertaking land evaluation is lack of sufficient skills, for instance in distinguishing land qualities from land characteristics or failure to deduce proper diagnostic factors for considered land qualities. Study areas can be delineated using differences in either of the factors of soil genesis or any other scientifically rigorous criteria. The presented results should also be realistic, for example having clay texture in a non-expanding soil (for example 1:1 clays) cannot be a major limitation to crop production. Similarly, having some ponding on a level land due to heavy rains cannot be a limitation in the long run. Suggested improvements should be socially acceptable, environmentally friendly and economically feasible.

\section{Conclusions and recommendations}

Soil workability, susceptibility to erosion coupled with low CEC in some profiles were the greatest production challenges. There is a need to apply manure to the soils to buffer the soil reaction, maintain high organic matter content, stabilize the CEC and also maintain nitrogen sources in the soil. Erosion control would prevent deterioration of the soil fertility. Suboptimal land use in the study area is the main challenge to yield increase, and therefore there is a need for land evaluation. Agricultural colleges need to consider inclusion of land evaluation concepts in the training curriculum as this will ensure that students are equipped with this paramount 
skill having a wide application beyond agriculture. This technique can be applied in a wide range of disciplines including engineering. There is a need for the government to fund these exercises for the benefit of the nation and the environment. Land evaluation coupled with precision agriculture can act as a panacea to food insecurity in different parts of the world.

\section{Abbreviations}

SMU: Soil Mapping Units; FAO: Food and Agriculture Organisation; UTM: Universal Transverse Mercator; GPS: Global Positioning System; GIS: Geographic Information Systems; AAS: atomic absorption spectrophotometer; Ksat: saturated hydraulic conductivity; CEC: Cation Exchange Capacity; SDGs: sustainable development goals.

\section{Acknowledgements}

The main author acknowledges Prof. J.P Mbuvi, University of Nairobi, for his generous financial support.

\section{Authors' contributions}

All authors of this research paper have directly participated in planning, execution and analysis of the study. All authors read and approved the final manuscript.

\section{Funding}

The authors have not received any funding or grant.

\section{Availability of data and materials}

Additional data may be availed on request to the authors through the corresponding author. We take legal responsibility for information, used procedures, data and results.

\section{Ethics approval and consent to participate}

This research work meets all the ethical guidelines, adhering to the legal requirements of my country.

\section{Consent for publication}

The authors confirm that there is no conflict of interest and agree with submission of the manuscript to your journal.

\section{Competing interests}

The authors declare that they have no competing interests.

Received: 18 February 2019 Accepted: 10 June 2019

Published online: 25 September 2019

\section{References}

1. Elsheikh R, Rashid A, Shariff BM, Amiri F, Ahmad NB, Kumar S, et al. Agriculture land suitability evaluator (ALSE): a decision and planning support tool for tropical and subtropical crops. Comput Electron Agric. 2013;93:98-110. https://doi.org/10.1016/j.compag.2013.02.003.

2. Rossiter DG. A theoretical framework for land evaluation. Geoderma. 1996;72:165-90.

3. Daigle JJ, Hudnall WH, Gabriel WJ, Mersiovsky E, Nielson RD. The National Soil Information System (NASIS): designing soil interpretation classes for military land-use predictions. J Terramech. 2005;42:305-20.

4. Seid NM, Yitaferu B, Kibret K, Ziadat F. Soil-landscape modeling and remote sensing to provide spatial representation of soil attributes for an Ethiopian watershed. Appl Environ Soil Sci. 2013;2013:1-11.

5. Zhoul HZ, Macdonald KB, Moore A. Some cautions on the use of geographic information system (GIS) technology to integrate soil site and area data data. Can J Soil Sci. 1991;394:389-94.

6. Zabel F, Putzenlechner B, Mauser W. Global agricultural land resourcesa high resolution suitability evaluation and its perspectives until 2100 under climate change conditions. PLOS ONE. 2014;9(9):1-12.
7. Sys CE, Debaveye J. Land evaluation. Part 1: principles in land evaluation and crop production calculation. In: General administration for development cooperation. Brussels, Belgium: Agricultural Publications; 1991. p. 274.

8. Abdelrahman MAE, Natarajan A, Hegde R. Assessment of land suitability and capability by integrating remote sensing and GIS for agriculture in Chamarajanagar district, Karnataka, India. Egypt J Remote Sens Sp Sci. 2016;19(1):125-41. https://doi.org/10.1016/j.ejrs.2016.02.001.

9. Taylor P, Sarkar A, Ghosh A, Banik P. Geo-spatial Information Science Multicriteria land evaluation for suitability analysis of wheat : a case study of a watershed in eastern plateau region, India. Geo-Spatial Inform Sci. 2014;17:37-41.

10. Rossiter DG, Wambeke AR Van. ALES Version 4. 65 User's manual February 1997 printing. 1997;1(February).

11. Rabia AH, Rabia AH, Terribile F. Introducing a new parametric concept for land suitability assessment introducing a new parametric concept for land suitability assessment. Int J Environ Sci Dev. 2013;4:15.

12. Jiitzold R, Kutsch H. Agro-ecological zones of the tropics, with a sample from Kenya. J Agric Trop Subtrop. 1982;83:15-34.

13. Mathu E, Mwea SK. A study on the engineering behaviour of Nairobi subsoil. ARPN J Eng Appl Sci. 2014;6:7.

14. Ingram JSI. Tropical soil biology and fertility : a handbook of methods. Soil Sci. 1994;157(4):265.

15. Nelson EW, Sommers LE. Total carbon, organic carbon, and organic matter. In: Sparks DL, editor. Methods of soil analysis: chemical methods, Part 3. Madison: Soil Science Society of America; 1996.

16. Black CA. Methods of soil analysis. Part I and II. Madison: Amer. Soc. Agron; 1965.

17. Bremner JM. Total nitrogen. In: Sparks DL, editor. Methods of soil analysis: chemical methods, Part 3. Madison: Soil Science Society of America; 1996.

18. Glendon WG, Doni OR. Methods of soil analysis Part 4:2644-289 No. 5. In: Dane JH, Topp GC, editors. Soil science society of America book series. Madison: SSSA, Inc; 2002.

19. Reynolds WD, Elrick DE, Youngs EG. Rings or cylinder infiltrometers (Vadose Zone) Methods of soil analysis. Part 4. Physical methods: 818-843 No. 5. In: Dane JH, Topp GC, editors. Soil science society of America book series. Madison: SSSA Inc; 2002.

20. Grossman RB, Reinsch TG. Bulk density and linear extensibility. In: Dane JH, Topp GC, editors. Methods of soil analysis, part 4: 201-228. Lincoln: USDA-NRCS, National Soil Survey Center; 2002.

21. Soil W, Reports R. World reference base for soil resources 2006. World Soil Resourc Rep. 2006;103:128.

\section{Publisher's Note}

Springer Nature remains neutral with regard to jurisdictional claims in published maps and institutional affiliations.

\section{Submit your manuscript to a SpringerOpen ${ }^{\odot}$ journal and benefit from:}

- Convenient online submission

- Rigorous peer review

- Open access: articles freely available online

- High visibility within the field

- Retaining the copyright to your article

Submit your next manuscript at $\boldsymbol{\nabla}$ springeropen.com 